Dušica Miladinović-Stefanović, LL.D., ${ }^{*}$ Assistant Professor,

Faculty of Law, University of Niš
ПРЕГЛЕДНИ НАУЧНИ ЧЛАНАК

UDK: 343.241-053.6

Рад примљен: 07.04.2015.

Рад прихваћен: 24.04.2015.

\title{
JUVENILE PRISON: REMARKS ON THE SPECIFIC CHARACTERISTICS OF REGULAR SENTENCING ${ }^{* *}$
}

\begin{abstract}
The system of the juvenile criminal law in the Republic of Serbia includes different mechanisms of social response to juvenile delinquency, including corrective orders, corrective measures and juvenile prison. This paper deals with the issue of determining a relevant sentence for juvenile offenders in trial proceedings. The legislator has provided a number of guidelines for these proceedings: the specific range of the juvenile prison sentence, the purpose of punishment, the degree of maturity of a juvenile offender, the time needed for his/her educational and vocational training, and all relevant circumstances envisaged in Article 54 of the Criminal Code. The previous statement reveals the focal points of examination and structural organization in this article, whose purpose is twofold: first, to explain the effect of the subject-specific legal provisions (aggravating and mitigating circumstances) envisaged in the Act on Juvenile Criminal Offenders and Protection of Juveniles in Criminal Law and, second, to establish how the general provisions from the Criminal Code are applied in this case, with special emphasis on their specific manifestations.
\end{abstract}

Key words: juvenile prison, purpose of punishment, aggravating and mitigating circumstances.

\footnotetext{
*dusica@prafak.ni.ac.rs

** This article is a result of the research conducted within the project "The Protection of Human and Minority Rights within the European Legal Space" (No. 179046), which has been financially supported by the Ministry of Education, Science and Technological Development of the Republic of Serbia.
} 


\section{Introduction}

The formal social response to juvenile delinquency in Serbia has gone through different stages of development. In the first developmental stage, which covered a quite long period of time and featured a larger number of diverse sources, a minor was perceived as "an adult delinquent in a miniature form" (Perić, 1979:5); it implied the same penalties for both adults and minors, including possible limitations in terms of duration and prohibition of awarding certain penalties for minors. The second stage was characterised by a significant emphasis on and acknowledgement of the specific status of juvenile offenders; given their ongoing psycho-physical development and socialisation processes, the legislator focused on the corrective measures and envisaged the juvenile prison sentence as the only criminal sanction (punishment) for minors. ${ }^{1}$ The third stage is based on the Act on Juvenile Offenders and Protection of Juveniles in Criminal Law (hereinafter: the Juvenile Criminal Offenders Act (JCOA) ${ }^{2}$. The most prominent characteristics of this Act are the selection and codification of the substantive juvenile criminal $\operatorname{law}^{3}$, as well as the reception of the concept of restorative justice as a doctrinal basis for upholding the idea on the protection of minors' rights and acting in their best interest. The aforementioned platform has led to introducing new mechanisms (such as corrective orders) which allow for the "diversification", i.e. diversion of the criminal proceedings. On the other hand, the system has preserved the traditional mechanisms: corrective measures and the juvenile prison sentence. There are several idiosyncratic features that distinguish the juvenile prison sentence from the punishment of imprisonment awarded to adult criminal offenders; these are: the specific normative framework; the specific requirements for sentencing and conditional release on parole; the exclusion of legal consequences of conviction by proscribing certain rights; restricting the circle of subjects who may be issued the information about prior convictions; specific statutes of limitations; and specific sentencing rules, which will be discussed further on in this paper (for more details about specific characteristics, see in: Jovašević, 2011: 431). The basic sentencing rule (Article 30, JCOA) indicates an eclectic approach to the subject matter; apart from the observance of the specific legislative framework, the specific purpose of punishment, the degree of juveniles' maturity and the time needed for the

1 It is valid from the moment of the entry into force of the Law on Amendments and Additions to the Criminal Code of FPRY, the Official Gazette of FPRY, No. 30/59.

2 The Official Gazette of the Republic of Serbia, No. 85/05.

3 Apart from being in line with contemporary tendencies in this area, this process may be justified by the fact that many criminal law principles and institutes are either inapplicable in the area of juvenile criminal law or insubstantial; therefore, it could also be viewed as a quasi- or para-criminal law (Stojanović, 2012: 338-339). 
educational and vocational training, this provision obliges the court to evaluate all relevant circumstances envisaged in Article 54 of the Criminal Code. ${ }^{4}$ This statement reveals the central themes and structural organisation of this article, whose aim is twofold: first, to explain the effect of specific provisions from the Juvenile Criminal Offenders Act (JCOA) and, second, to establish how the general provisions from the Serbian Criminal Code are applied in this case, with emphasis on their specific manifestations.

\section{Remarks on the penal framework and purpose of juvenile prison}

The first guiding principle in the process of sentencing is the scope of juvenile prison sentence, generally ranging from the minimum sentence of six months to the maximum sentence of five years, except in those cases where a minor stands trial for a criminal act which is punishable by a 20 -year term of imprisonment or more, or in case of a concurrent commission of at least two criminal acts which are punishable by a term of imprisonment exceeding 10 years, when the general maximum is reduced to ten years (Article 29, JCOA). In comparison with the former legal solution, this legal provision sustained a significant change; it has been drastically narrowed given that the formerly prescribed minimum sentence was one year and the maximum sentence was ten years. Thus, the court's room for manoeuvre was practically cut down by half. It ultimately yielded negative reactions of some theorists, legal practitioners, prosecutors and judges specializing in juvenile crime (Ignjatović, 2004: 544), who raised a series of objections. The first contested issue was the impossibility of adjusting the punishment to the merits of a specific case, particularly in cases where the court estimates that a five-year term of imprisonment is not an adequate response to the commission of a serious juvenile crime which does not meet the criteria for reducing the penalty to the maximum 10 -year term of imprisonment. The minimum term of imprisonment was also disputed; apart from the common objections on short-term imprisonment, the opponents particularly focused on the short period of time for organising and conducting an effective treatment which would be beneficial for a juvenile offender. Briefly, the new legal provision was said to be "undermining the logic of a good penal system" (Ignjatović, 2004: 545), which is supposed to be flexible and adaptable to personal characteristics of different perpetrators and distinct circumstances in different criminal acts. ${ }^{5}$

4 The Official Gazette of the Republic of Serbia, No. 85/05, 88/05-corr., 107/05-corr., 72/09, $111 / 09,121 / 12,104 / 13$ and 108/14.

5 This was the reason to embark on preparing a Draft Act to amend and supplement the Juvenile Criminal Offenders Act, which proposed that the lower general maximum of 5 years' imprisonment should be increased to 7 years' imprisonment. As for criminal offences punishable by a 15-year term of imprisonment (instead of the current twenty) or more, 
There are reasonable grounds to challenge the empirical foundation of the new framework and examine its justifiability in correlation to the scope, structure and dynamics of juvenile crime. Does the legal practice reflect any significant changes in these indicators, which may eventually justify the idea on the need to institute less repressive measures? The statistical data from 1999 to 2005 indicate some stagnation in the total number of registered, charged and convicted minors, which is contrary to (rather frequent) arbitrary estimates on the permanent rise of this form of social pathology; concurrently, the data include a remark on the notable increase of the number of juvenile delinquents in the total population of juveniles, as well as a rise of criminal acts involving elements of violence (Ilić, 2007: 298). The last two pieces of information are not in the least encouraging and they should not be overshadowed by the initial observation on the mild stagnation in juvenile crime. On the other hand, it is worth noting that the social response in the given period was primarily based on correctional and educational measures rather than punishment; thus, the ratio between the imposed correctional measures and juvenile prison was $99.1 \%$ to $0.9 \%$; yet, the scope of corrective measures applied in juvenile prison was still very low $(3,7 \%$ ) as compared to the total total number of corrective measures (Ilić, 2007: 300). All this accounts for the fact that the response was based on awarding minimal penalties and using non-repressive mechanisms, primarily those of a non-institutional character.

A critical evaluation of the new framework of the juvenile prison sentence would be incomplete without an overview of comparative law. In this regard, special attention is given to the neighbouring countries, primarily the former Yugoslav republics, not only because of the similar social circumstances but also because the starting points in the development of their legal systems were similar to ours. The penal systems of Montenegro, ${ }^{6}$ the Republic of Srpska, ${ }^{7}$ Croatia $^{8}$ and Slovenia ${ }^{9}$ include the same minimum and maximum of juvenile prison penalties

there was a proposal for imposing a 10-year term of imprisonment (Milošević, 2008: 284). However, these changes have not been adopted to the present day.

6 Article 33, par. 1 of the Act on the Treatment of Juveniles in Criminal Proceedings, the Official Gazette of Montenegro, No.64/11. The earlier legal solution prescribed a minimum of six months' imprisonment and a maximum of eight to ten years (more in Jovašević, 2010: 148).

7 Article 51, par. 1 of the Act on Protection and Treatment of Children and Juveniles in Criminal Proceedings, the Official Gazette of the Republic of Srpska, No. 13/10. The tendency towards a less repressive social response is obvious in the legislation of the Republic of Srpska, given that the previous legal solution prescribed a range_from one to ten years' imprisonment (Babić, Marković, 2008: 508).

8 Article 25, par. 1 of the Juvenile Courts Act, the Official Gazette of the Republic of Croatia, No. 84/11, 143/12 and 148/13.

9 Cited according to Selinšek, 2007: 335. 
as ours, whereas the penal system of FYR Macedonia includes the range of one to ten years' imprisonment. ${ }^{10}$ As for other countries, the German legal system (for example) includes the same penal framework as the one envisaged in Serbia. ${ }^{11}$

However, if the scope is viewed in relation to other provisions, it is clearly in line with the general tendency to make the response to juvenile crime less repressive. This tendency is also present in many other legal provisions, including the sentencing rule that the imposed sentence shall include only full months and years, ${ }^{12}$ the new requirements for the application of parole, ${ }^{13}$ and others.

Modelled on previous legal solutions, the new legislative act includes the rule which prescribes that a minor cannot be sentenced to a term of imprisonment longer than the specifically prescribed punishment for the given crime, but the court is not bound to apply the minimum term of imprisonment. This rule does not actually have any practical significance for all criminal acts whose specific minimum is the same as the general maximum of the juvenile prison sentence. However, if the minimum is higher, the court is obliged to step out of the penal framework which is prescribed for the given crime; it practically implies a modification of the institute of mitigating the punishment, which can obviously be applied regardless of the conditions provided in the general criminal law. On the other hand, the fact that a minimum of less than six months is prescribed for a specific criminal act is also irrelevant given that the juvenile prison sentence cannot be awarded for less than six months.

The second guiding principle of regular sentencing is the purpose of juvenile prison sentence. To a certain extent, it coincides with the purpose of corrective measures, particularly in the segment referring to the reintegration of juveniles in the social community (Article 10, par. 1, JCOA). The necessary assumptions for successful reintegration (as the final outcome) are the development and strengthening of a minor's personal responsibility, as well as the correction and proper development of his/her personality, which are achieved by means of supervision, assistance and vocational training. Yet, irrespective of these

10 Article 44, par. 2 of the Juvenile Justice Act, the Official Gazette of the FYR of Macedonia, No. 87/07, 103/08, 161/08 and 145/10.

11 Article 18, Jugendgerichtsgesetz. For a detailed review of this decision in comparative law, see in Knežević, 2010:84 and in Radulović, 2010: 160-162.

12 This rule has replaced the earlier one where the sentence was expressed in full years and half a year.

13 There is a partial overlapping in the old and the new requirements. Therefore, a minor is required to have served one third of the sentence before being releases; the difference is that, under the former requirements, a minor could not have been released before the completion of one year; under the new requirements, a minor cannot be releases on parole before the completion of six months. 
specific features, it is still penalty whose purpose is supplemented with general prevention elements. Thus, the sentence and the execution of the awarded penalty should exert an impact on other minors and deter them from committing criminal acts in the future (general prevention); on the other hand, it should also exert a stronger impact on a specific juvenile offender and deter him/her from further commission of crime (specific prevention). To sum up, we may conclude that juvenile prison sentence, just like other forms of punishment, features certain retributive elements; however, it should be clearly noted that the purpose of juvenile prison sentence is primarily of correctional and educational nature.

\section{Minors' level of maturity and time needed for their educational and vocational training}

The minor's level of maturity is the first specific circumstance which the court should take into account in the process of sentencing a minor to serve time in juvenile prison. It is a new term, given that earlier regulations referred to the level of mental development. In the domestic theory, there is no unique approach to the interpretation of this term. While some believe that it corresponds to the concept of sanity in the general criminal law, implying the minor's ability to comprehend the significance of his/her acts and to control his/her actions (Perić, 2005: 85, Lazarević, Grubač, 2005: 54), others deny it stating that maturity as a circumstance relevant for sentencing a minor to juvenile prison represents the so-called general and not specific maturity (sanity) as the basis of culpability (in particular, Drakić, 2010: 52, although some authors can be indirectly connected to this attitude, see Radulović, 2010: 155). ${ }^{14}$ Qualifiers such as 'general' and 'specific' unambiguously indicate different scopes of these terms. Hence, general maturity refers to the personality as a whole, i.e. "to the level of development of organs and psychological functions of a concrete minor in relation to the social environment which surrounds him/her" (Drakić, 2010: 52, previously also Singer, 1992: 205). The second point of view seems to be more acceptable, especially on the basis of a systematic interpretation. Starting from the assumption of coherence of the criminal law system, the arising question is why the legislator would include the notion of sanity into the process of sentencing twice: first, through a circumstance of maturity and, then, through a circumstance of the degree of culpability (given that it is already its constituent part). Even assuming that maturity (perceived in the sense of juvenile sanity) is specific and different from the sanity of adults, there would still be no justification because, as such, it would surely be included in the notion of culpability, due to the lex

14 There is also a third group of theorists who only state the relevant circumstances, without engaging themselves into the problems of interpretation (Knežević, 2010: 88, Jovašević, 2010: 154, Škulić, 2011: 307). 
specialis principle. However, the issue that perhaps confuses legal experts does not confuse psychiatrists, who are called as experts to state their opinions on this matter. Therefore, forensic psychiatry particularly emphasizes that, in the case of older minors, the expert does not only express the opinion on a minor's bio-psycho-social maturity but also evaluates the minor's ability to understand the significance of his/her act and the ability to control his/her actions (Krstić, 1996: 166, Ćirić, 2013: 297, etc.), which clearly makes a distinction between (general) maturity and sanity. A direct consequence of the described concept of general maturity leads to the fact that maturity is not observed in relation to a given criminal act, nor is it evaluated on the basis of the actual time when the act was committed, but within the framework of the minor's general behaviour and within a wider time interval. On the contrary, all theorists who claim that maturity and sanity are synonymous terms (which is a generally accepted attitude) insist on the fact that it is evaluated tempore criminis and in relation to the committed criminal offence (Perić, 2005: 85, Lazarević, Grubač, 2005: 54). As it seems more reasonable to observe the notion of maturity in its wider sense, the court should be warned about the possible risk of digression and generalisation. The evaluation of the smallest segments of one's bio-psycho-social profile is unnecessary; therefore, all the facts that are unrelated to the evaluation of the purpose of punishment should not be of interest to the court.

The second specific circumstance is the time needed for the educational and vocational training. As compared to the earlier formulation of this circumstance, there is evidence of change, which is reflected in the exclusion of the term "re-education" (correctional education). Although the lack of linguistic finesse might lead someone to to believe that these terms as synonyms, this is not the case. The term "re-education" implies a necessary assumption of a lower or higher degree of negative, deeply rooted and unacceptable attitudes and habits; on the other hand, the term "education" is slightly more neutral and places less emphasis on the aforementioned assumption of stigmatisation. However, with or without the word "re-education", this circumstance nevertheless underlines the specific preventive character of juvenile prison. To a certain extent, insisting on the duration of penalty only within the time period which is needed for the educational and vocational training of minors indirectly points to the criteria for the evaluation of the significance of the circumstances prescribed in Article 54 of the Criminal Code. Therefore, the top of the list includes the circumstances pertaining to a juvenile offender whose influence should be more dominant than the other factors. ${ }^{15}$

15 On the contrary, when it comes to adult perpetrators, the issue of greatest significance in the process of regular sentencing is the severity of violating or endangering the protected values (Lazarević, 2011: 258). 


\section{Specific features of general mitigating and aggravating circumstances envisaged in the Criminal Code}

The list of mitigating and aggravating circumstances places the degree of culpability at the top. There are no separate, special rules in the Juvenile Criminal Offenders Act for the notion of culpability; therefore, it is assumed that the general rules from Article 22 of the Criminal Code are applied here too. ${ }^{16}$ This necessarily implies that a minor was sane, that he/she acted with intent or negligently, and that he/she was aware or that he/she was obliged to be aware or might have been aware of the illicit nature of the criminal act. Sanity, or maturity in its narrow sense, would imply a minor's psychological capacity which enables him/her to grasp the significance of his/her act within a common causal sense, and to restrain the stimuli driving him/her to commit the criminal act. In psychological terms, it includes intellectual and emotional maturity and, in the case of sex crimes, it also includes psycho-sexual maturity (Hrnjica, 2003: 202207). Intent and negligence, together with the awareness of the illicit nature of an act, are also commonsense concepts. However, is it all that simple? Apparently not, as the legislator has proposed a high degree of culpability as a condition for imposing a juvenile prison sentence. ${ }^{17}$ Therefore, any form of psychological content which is incompatible with the high degree of culpability would never be included in the process of sentencing because its inclusion would automatically exclude the option of imposing a juvenile prison sentence. The court would then

16 As a slight digression, we should point out to a tentative, uncertain and insufficiently profiled attitude of the legislator on the position and role of culpability in juvenile justice. It is specifically mentioned as a highly qualified condition for imposing the juvenile prison sentence. This is not the case with correctional measures; thus, culpability is not a precondition either for imposing these measures or for their duration. This is clearly confirmed by the procedural rule which states that the decision on imposing a correctional/educational measure shall not proclaim a minor guilty. Besides, a terminological analysis of basic provisions stating that the Act is applicable to "juvenile perpetrators of criminal offences" (Article 1, JCOA), thus excluding the application of this Act against "a person under fourteen years of age at the time of commission of an unlawful act which is prescribed as a criminal offence" (Article 2, JCOA), clearly confirms that the starting point has been the concept of a criminal offence envisaged in the Serbian Criminal Code, which includes the notion of culpability as a constituent element of crime. How can this now be correlated with the rule that culpability does not affect the imposition of correctional measures? There is simply no way to do that because it is a result of the legislator's inconsistency which calls for future corrections de lege ferenda, either by envisaging culpability as a condition for imposing corrective measures or by replacing it with another illicit act which is prescribed as a criminal offence.

17 The prerequisites for imposing a juvenile prison sentence are as follows: that the criminal act has been committed by an elder juvenile offender; that the committed criminal act is punishable by a term of over 5 years' imprisonment; and that the imposition of a connectional education measure would not be justified due to a high degree of culpability as well as the nature and gravity of the committed offence (Article 28, JCOA). 
be forced to choose something else from the available registry of penalties for minors. In order to impose some boundaries on the court's potential scope of influence, it is necessary to start from sanity and the possibility of determining the degrees of sanity. Complete sanity and a higher degree of culpability go "hand in hand", and there is nothing disputable about it, but, what about a lower or substantially lower degree of sanity? Here too, opinions are divided, starting from the attitude that even a slightly lower degree of sanity is completely incompatible with a high degree of culpability (Perić, 2005: 86 and further, Radulović, 2010: 151) to entirely opposite claims (Drakić, 2010: 57). Given that a lower degree of sanity is not a monolithic category and that it can be graded, it may be concluded that diminished capacity may not always annul a high degree of culpability, especially in cases involving a slightly lower degree of sanity. On the other hand, in cases concerning minors, there is a consensus that a high degree of culpability cannot be grounded on a substantially lower degree of sanity. Once again, this underscores the specific features of minors as a social category, given the fact that a substantially lower degree of sanity in adult offenders does not necessarily exclude intent. In this sense, intent can serve as a compensation for the low degree of sanity, thus increasing the degree of culpability, providing that there is awareness about the illicit nature of the act. It should also be noted that the sanity of adults is presumed (although the presumption may be contested), whereas the sanity of minors has to be proven. This is simply a consequence of the minors' basic features and on-going development rather than a consequence of an assumption of some form of pathology.

There is no doubt that a high degree of culpability can be proven on the basis of proven intent. On the contrary, negligent behaviour is usually regarded as its antipode. Certain authors point out that the aforementioned attitude is denied in practice because sometimes negligence is a cover for an inconsiderate, arrogant, completely disinterested and utterly irresponsible behaviour of minors towards the wellbeing of others (Drakić, 2010: 57, Knežević, 2010: 84). This means that in the process of deter mining the degree of culpability, the court, as a rule, deals with intent and, only in particular cases, with negligence. It should be noted that a small number of negligence cases is a result of a small number of these acts, which are associated with juvenile prison sentence and additionally narrowed by the condition concerning the specifically prescribed penalty (for a criminal act punishable by a proposed penalty of more than five years). However, some theorists warn that negligence should not be connected with the possibility of imposing the juvenile prison sentence as it would be "a detour from the restrictive approach in the process of punishing minors towards the extensive interpretation, which is definitely undesirable in this type of sanction" (Radulović, 2010: 151). 
The presence of minors' awareness about the illicit nature of a criminal act is grounded on the so-called moral and social maturity. A morally mature individual is aware of social demands and expectations, and he/she is capable of complying with them not out of fear of sanctions but because he/she understands the benefits stemming from the compliance both for himself/herself and for others (Hrnjica, 2003: 207). Social maturity indicates the minor's ability to integrate into the society, i.e. to establish successful relations on the individual/group level (Hrnjica, 2003: 204). The concept of awareness about the illicit nature of the act does not have any specific or distinctive meaning and it should be understood in general commonsense terms, as a lay concept. The specific feature here is the need for a higher degree of caution in the process of establishing the presence of such awareness in juveniles, primarily because of their young age and maturity. After all, they are just minors. In comparison to adults, the constitution of a minor's personality may make it more difficult for him/her to become aware of the illegality of certain behaviour. However, in order to get the proper picture, the entire process should include the data regarding the most common misdemeanours (delicts) performed by minors. Statistics show that the the most common criminal acts committed by minors are offences against property, public order and peace, life and limb.$^{18}$ This common knowledge provides a high level of certainty for the assumption that a minor is a suitable addressee of the norm, which could not be claimed with certainty for some other cases of incrimination, especially those from the secondary legislation.

Sentencing a minor to juvenile prison also includes motives, given that the evaluation of culpability, which is necessary in order to choose the proper measure of this penalty, would be incomplete without taking them account. We should also bear in mind that motives contribute to "putting together" of a general ethical picture about the personality of any individual, including a juvenile perpetra-

18 To illustrate: the statistical data for the year 2013 (author's note: at the time of preparing this paper, the data for 2014 were not processed) show that there was a total number of 1,554 convicted older minors. A total of 903 minors (58.11\%) committed a criminal offence against property, 201 minors (12.93\%) committed an offence against public order and peace, and 184 minors (11.84\%) committed an offence against life and limb. The list includes offences against: safety of public traffic (62 minors), marriage and family (17), rights and freedoms (13), state authorities (9), gender rights (8), environment (7), general public safety (5), judicial system (5), legal transactions (5), constitutional system and security (3), humanity and other values protected under international law (3), military (2), intellectual property (2), economy (2), honour and reputation (1), safety of computer data (1); eight minors were convicted for acts falling within the scope of secondary criminal legislation but there are no details about the nature of these acts (source: the Statistical Office of the Republic of Serbia, 2014: 50-51). 
tor. ${ }^{19}$ The nature of this article calls for the selection of those motives which are assumed to be more common in minors than in adults. A typical example are the so-called motives of adventure, which occur due to wrong or negligent upbringing, which leads a minor to identify him/herself with negative models of behaviour: "An exaggerated influence of trashy literature and films, whose lead characters are strong, powerful, great fighters, well-armed, wealthy and extremely dynamic, leaves a strong impression on young people, whose reality and everyday life is different, bleak, full of poverty and privation. Dynamics, glitz, wealth, luxury, cars, and beautiful women fascinate and, in a metaphorical sense, hypnotise both children from poor workers' barracks and mouldy rented rooms as well as prodigal and spoiled children of wealthy parents who have given them everything except love, working habits and modesty" (Simonović, 1991: 585-586). The motives of adventure can be embodied in different forms of illicit behaviour; since they lead to the creation of a crude and unrefined hedonistic life orientation, they usually guide a minor towards criminal acts against property. Besides motives of adventure, we should also mention the motives of hooliganism, which in a certain number of cases create a psychological background of violent behaviour, participation in fights, endangerment of safety, causing severe body injuries, committing homicides and similar criminal acts. In psychology, there is no generally accepted explanation of the motives of hooliganism; some believe that these motives stem from the need to release the accumulated negative energy; others think that this is a complex motive which is produced by combining wickedness, revenge and jealousy; there are also those who speak about a sadistic desire to prove oneself to others and to oneself through the manifestation of power over other people (Simonović, 1991: 534-535). Either way, the occurrence of such motives proves the existence of a negative and undesirable system of values, which should be taken into consideration in the process of sentencing a juvenile to prison because the time needed for correction depends on how deeply rooted these values are. Other motives which are characteristic for minors are the motives of social and psychological compensation where the act is committed with the aim of compensating real or imaginary failures and imperfections, as well as the status motive, the motive of entertainment and the motive of vengeance (Škulić, 2011: 61).

The generally accepted understanding that the severity of violation or endangerment of the protected value points to the consequence of a criminal act, in

19 Their significance is constantly emphasised within the frameworks of juvenile criminal law. Hence, motives have to be taken into account in the process of choosing a correctional measure. Yet, the fact that is confusing here is that culpability is not considered to be the basis for imposing correctional measures, in which case it seems illogical to insist on the motives. In our opinion, this is another proof that the legislator has not completely resolved the issue concerning the position of culpability in the juvenile criminal law system. 
its concrete and committed form, has generated certain dilemmas regarding the juvenile prison sentence. This conception has not been disputed per se but it has caused problems in the context of earlier conditions for imposing the juvenile prison sentence. In that sense, the concept of "severe consequences of an act" divided theorists and practitioners into those who thought that the juvenile prison sentence was automatically excluded if the act was qualified as "an attempt" and those who tried to find some highly disputable arguments for its application. The majority were prone to accept the interpretation that in this case the juvenile prison sentence was not an alternative (Perić, 1995: 47) even though they considered that it was not always criminally and politically justified; accordingly, they advocated the intervention de lege ferenda. In the Juvenile Criminal Offenders Act, the formulation "severe consequences of the offence" was replaced with the formulation "nature and gravity of the offence" (Article 28, JCOA), which has given this condition an entirely new, wider sense. The old dilemma is no longer valid considering that this provision is interpreted in such a way that the juvenile prison sentence can be imposed in either case: when the act was committed and when it was only attempted (Perić, 2005: 87).

Considering the circumstances under which an criminal act is committed, there are two facts which seem significant. First of all, in comparison to a common adult person, it is much harder for a minor to resist when "the opportunity calls." Psychological characteristics of a developing personality make it more difficult for minors to fight the impulses and to control their behaviour. Secondly, similar effects can be achieved by the influence of other individuals: parents, a trustworthy person or a group of peers. Minors are much more susceptible to influences and less resistant to actions of others, irrespective of how these actions are manifested: either in the form of pressure or only through the presentation of possible benefits of committing the act. When it comes to an offence committed by a group of minors, we should bear in mind that it may sometimes include a minor who is not actually very "enthusiastic" about committing a crime but does not want to give up or to refuse to participate since he/she would be the subject of disrespect, ridicule and rejection; such situations are much more frustrating for minors, who are still developing their identity and searching for their place in society, than for adults.

Another important element which should be singled out from the multifaceted concept of 'life history' is the concept of previous convictions or absence of criminal record. In this context, the inefficiency of a previously imposed correctional measure is viewed as one of the indicators that it may be necessary to impose a juvenile prison sentence, whereas the previous convictions to a juvenile prison sentence are taken as an aggravating circumstance. The process of obtaining information from the registry of prior convictions to serve a juvenile prison 
sentence is regulated by referral to Article 102, par. 2 of the Criminal Code (Article 34, JCOA). The information about the imposed correctional measures may be issued only upon the request of the competent court, the public prosecution office and the social service (guardianship) authority (Article 27, par. 1, JCOA). But, no information can be provided on the correctional measures imposed for criminal acts which are punishable by a fine or a term of imprisonment up to three years, if the person whose information is requested has attained the age of 21 .

The young age and general characteristics of the population of minors also call for some specification or modelling of personal life circumstances. Thus, the distinctive circumstances within the minor's primary family unit are given priority and regarded as highly relevant in sentencing. In contrast, in an insignificant number of cases, the process of sentencing may include a minor's marital status, parenthood or employment. Yet, a low incidence of these factors in the population of minors statistically reduces the probability that these factors will influence the choice of penalty. On the one hand, the specific characteristics of minors' age and personality may lead to the marginalisation of certain facts; on the other hand, they may also contribute to introducing some other facts (such as the fact that the offender is attending school on a regular basis), which are hardly ever related to adults.

In the aetiology of juvenile crime, it has been generally recognized that the family unit, as a micro-social factor, is the most significant of all social factors (Konstantinović Vilić, Nikolić-Ristanović, Kostić, 2009: 229). Therefore, the court should pay attention to the fact whether perpetrators come from deficient or degraded families. A deficient and incomplete family, most frequently due to the parents' divorce, can cause an emotional insecurity and frustrating feelings of alienation and rejection, which very often produce destructive forms of behaviour. A more detrimental impact is produced by a degraded family, marked by a negative atmosphere, disrupted relations between the family members in various combinations, and frequently the presence of some form of social pathology in parents (alcoholism, substance abuse, prostitution, gambling or engaging in criminal acts). The constant presence of tension, conflicts, arguments and physical and psychological violence compromises the process of social adaptation. Parents, as negative role models, greatly contribute to the creation of negative personality traits, aspirations and beliefs of minors. A special form of this type of family is the so-called criminogenic family environment, where the parents actively encourage their children to be delinquents and raise them in that direction (Konstantinović Vilić, Nikolić-Ristanović, Kostić, 2009: 230). In extreme conditions, parents use force in order to make their child commit criminal acts; however, the legal significance of this phenomenon is not reflected through the process 
of sentencing but through some other criminal law institutes. Even though the asocial behaviour, neglect and inadequate upbringing as consequences of such family circumstances cannot be attributed to a minor, they directly influence the time needed for his/her correctional education. Putting the "problematic" families aside, a mitigating circumstance may be a lack of parental control, which even does not have to be regular and substantial; it is sufficient that it has contributed to the minor's commission of the act.

Apart from the family unit, another significant factor of socialisation is school. In this sense, the school environment is one of the primary social groups where the minor's personality is formed. It is indisputable that that the evidence of a child's social adaptation is a demonstrated positive behaviour at school, regular attendance, no-conflict relations with others, meeting the school requirements and duties, etc. However, all these elements are seldom taken into consideration in the course of sentencing juvenile offenders, particularly considering that some empirical research have shown that minors who are in conflict with the law are almost as a rule in "conflict with the school" (Konstantinović Vilić, Nikolić-Ristanović, Kostić, 2009: 375; Radulović, 2010: 161). The research results indicate that low academic achievement, grade failure and repetition, truancy, bad relationships with school peers, non-acceptance and disrespect of teachers' authority constitute a typical pre-delinquent image of a juvenile offender. Such attitude towards school and education reflects another aspect of neglect and abandonment.

Another legal circumstance worth mentioning is detention of a juvenile offender after the commission of the act; however, it does not include any specific features which could be taken into account in the process of sentencing minors to juvenile prison. The only notable issue may be the financial status of minors, who are largely unemployed and without any personal income or property; this fact may have a significant impact on their financial capacity to compensate the victim for the incurred damage or harm, even if they may be willing to do so.

Minors' property status is the only absolutely irrelevant fact provided in the Criminal Code. As one's property status is specifically related to monetary penalty (fine), there is not point to speak about it in the context of juvenile prison sentence.

Another specific circumstance that may be worth mentioning is the sentence for hate crimes, which was introduced in the new provisions of the Criminal Code of $2012^{20}$; yet, a relatively short period of its usage does not provide for a substantial review of its application in our legal practice. The experiences

20 If a criminal act has been committed out of hate, due to racial or religious affiliation, national or ethnical affiliation, gender, sexual orientation or gender identity, this circumstance 
from some other countries point to the assumption that juvenile perpetrators of hate crimes may relatively often be sentenced in the course of regular court proceedings. In Germany, for example, it has been determined that almost $30 \%$ of perpetrators of hate crimes were minors aged 16 or 17 , at the time of committing the act, whereas two thirds of the offenders were below the age of 20. These results were confirmed by the studies conducted in the USA (Pavlović, 2009: 332). Furthermore, some forms of hate crime (such as the so-called 'crimes for fun') are committed by minors, most frequently acting in groups (gangs); they are commonly aimed against a previously unknown victim and committed for fun, "to slay boredom" or to deserve respect of other "like-minded" youngsters (Pavlović, 2009: 327).

\section{Concluding remarks}

The primary focus of this article has been to elaborate on the interpretation of specific circumstances and specific features in the general mitigating and aggravating circumstances envisaged in the Serbian Criminal Code. However, in order to provide a comprehensive understanding of the process of sentencing juvenile offenders, it is necessary to make a short analysis of the policy for imposing penalties on juvenile offenders. The analysis shows that courts very rarely choose the option of juvenile prison and that they primarily opt for corrective measures. Thus, the prevalence of juvenile prison sentence in the overall structure of imposed penalties may be said to be almost irrelevant because it is around one percent on the average..$^{21}$ This clearly confirms the opinion that juvenile prison sentence is "the last resort" which comes into play only if all other options are exhausted. However, it does not make the problem of sentencing minors to juvenile prison any less significant, primarily due to the sensitivity of this issue. Besides, the data from the observed ten-year period indicate that courts most frequently impose the juvenile prison sentence for a period of over six months up to two years; it means that they use the lower half of the available sentencing scale, which is evident in the Table provided below. ${ }^{22}$

\footnotetext{
will be taken by the court as an aggravating circumstance, unless it is prescribed as the essential element of a criminal act (Article 54a, Criminal Code).

21 The exact data for the period from 2004 to 2014 are as follows: $0.77 \%, 0.48 \%, 1.58 \%$, $1.37 \%, 1.71 \%, 0.52 \%, 0.99 \%, 0.15 \%$ and $0.51 \%$. The prevalence is calculated on the basis of data contained in the official publication of the Statistical Office of the Republic of Serbia, 2014: 49.

22 The data are taken from the official publication of the Statistical Office of the Republic of Serbia, 2014: 49.
} 


\begin{tabular}{|c|c|c|c|c|c|}
\hline Year & $\begin{array}{l}\text { 5 to 10-years' } \\
\text { term of } \\
\text { juvenile } \\
\text { imprisonment }\end{array}$ & $\begin{array}{l}\text { 2 to 5 years' } \\
\text { term of } \\
\text { juvenile } \\
\text { imprisonment }\end{array}$ & $\begin{array}{l}\text { 1 to 2 years' } \\
\text { term of } \\
\text { juvenile } \\
\text { imprisonment }\end{array}$ & $\begin{array}{l}\text { 6 months to } \\
\text { one-year term } \\
\text { of juvenile } \\
\text { imprisonment }\end{array}$ & Total \\
\hline 2004 & 4 & 2 & - & $4(40 \%)$ & 10 \\
\hline 2005 & 2 & 1 & - & $4(57.1 \%)$ & 7 \\
\hline 2006 & 4 & 3 & - & $10(58.8 \%)$ & 17 \\
\hline 2007 & 1 & 4 & - & $25(83.3 \%)$ & 30 \\
\hline 2008 & 1 & 7 & - & $9(52.9 \%)$ & 17 \\
\hline 2009 & 2 & 4 & - & $13(68.4 \%)$ & 19 \\
\hline 2010 & - & 1 & - & $4(80 \%)$ & 5 \\
\hline 2011 & 1 & 5 & - & $7(53.8 \%)$ & 13 \\
\hline 2012 & - & - & - & $2(100 \%)$ & 2 \\
\hline 2013 & 3 & 2 & - & $3(37.5 \%)$ & 8 \\
\hline
\end{tabular}

Finally, the remaining question is what kind of developments are to be expected in the future policy for sentencing juvenile offenders, particularly taking into account that our theory contains many different suggestions not only concerning the juvenile prison sentence concerning the entire penal system for minors. Some of these suggestions could have a significant impact on the wider use of juvenile prison sentence, such as the suggestion to provide such penalty for younger minors if the committed criminal offence is punishable by a term of 30 to 40 years' imprisonment (Perić, Milošević, Stevanović, 2008: 160-161); yet, such proposals are most unlikely to be put into effect. It is much more realistic to develop the penal system by introducing alternative sanctions, which may eventually reduce the application of juvenile prison sentence as the "last resort." More alternatives would logically imply fewer prison sentences. A possible introduction of monetary penalty (fine), which is already part of the Misdemeanour Act, is fully recognized in the comparative juvenile criminal law and envisaged in international documents. The introduction of conditional sentence (see more in Ćorović, 2013: 49-62 and Škulić, 2011: 166) could contribute to a less repressive approach to sentencing juvenile offenders, provided that there are no significant changes in juvenile crime trends.

Translated by Nikola Tatar, Gordana Ignjatovic 


\section{Bibliography}

Babić, M., Marković, I. (2008). Krivično pravo, Opšti deo. Banja Luka: Pravni fakultet

Drakić, D. (2010). O krivičnoj odgovornosti maloletnika. Sremski Karlovci, Novi Sad: Izdavačka knjižarnica Zorana Stojanovića

Zakon za maloletnička pravda. Služben vesnik na RM. Br. 87(2007), 103 (2008), 161 (2008) i 145 (2010)

Zakon o zaštiti i postupanju sa djecom i maloljetnicima u krivičnom postupku. Službeni glasnik RS. Br. 13 (2010)

Zakon o izmenama i dopunama Krivičnog zakonika FNRJ. Službeni list FNRJ. Br. 30 (1959)

Zakon o maloletnim učiniocima krivičnih dela i krivičnopravnoj zaštiti maloletnih lica. Službeni glasnik RS. Br. 85 (2005)

Zakon o postupanju prema maloljetnicima u krivičnom postupku. Službeni list CG. Br. 64 (2011)

Zakon o sudovima za mladež. Narodne novine RH. Br. 84 (2011), 143 (2012) and 148 (2013)

Ignjatović, Đ. (2004). Maloletničko krivično pravo između bolećljivosti i retributivnosti. Pravni život. 9. 529-553

Ilić, Z. (2007). Kriminalitet mladih i reforma pravno-institucionalne zaštite u Srbiji. U Ignjatović, Đ. (Prir.). Stanje kriminaliteta u Srbiji i pravna sredstva reagovanja, I deo. Beograd: Pravni fakultet. 296-313

Jovašević, D. (2010). Položaj maloletnika u krivičnom pravu. Niš: Centar za publikacije Pravnog fakulteta.

Jovašević, D. (2011). Primena kazne maloletničkog zatvora - stanje i mogućnosti. Teme. 2 (XXXV). 421-439

Jugendgerichtsgesetz. http://www.gesetze-im-internet.de/bundesrecht/jgg/ gesamt.pdf Accessed on $7^{\text {th }}$ March 2015

Knežević, S. (2010). Maloletničko krivično pravo (materijalno, procesno, izvršno). Niš: Centar za publikacije Pravnog fakulteta

Konstantinović Vilić, S., Nikolić-Ristanović, V., Kostić, M. (2009). Kriminologija. Niš: Pelikan print

Krivični zakonik. Službeni glasnik RS. Br. 85 (2005), 88 (2005-ispr.), 107 (2005ispr.), 72 (2009), 111 (2009), 121 (2012), 104 (2013) and 108 (2014) 
Krstić, B. (1996). Sudska psihijatrija. Niš: Studentski kulturni centar

Lazarević, Lj. (2011). Komentar Krivičnog zakonika Republike Srbije. Beograd: Službeni glasnik

Lazarević, Lj., Grubač, M. (2005). Komentar Zakona o maloletnim učiniocima krivičnih dela i krivičnopravnoj zaštiti maloletnih lica. Beograd: Justinijan

Milošević, N. (2008). Planirane izmene u Zakonu o maloletnim učiniocima krivičnih dela i krivičnopravnoj zaštiti maloletnih lica. U Bejatović, S. (Prir.). Krivičnopravna pitanja maloletničke delinkvencije (str. 277-290). Beograd: Srpsko udruženje za krivičnopravnu teoriju i praksu

Pavlović, M. (2009). Specifične karakteristike učinilaca i žrtava zločina mržnje. Zbornik radova. 3. 325-346

Perić, O. (2005). Komentar Zakona o maloletnim učiniocima krivičnih dela i krivičnopravnoj zaštiti maloletnih lica. Beograd: Službeni glasnik

Perić, O. (1995). Komentar krivičnopravnih propisa o maloletnicima, propisi SRJ, $R S$ i CG. Beograd: Službeni glasnik

Perić, O. (1979). Maloletnički zatvor - primena i izvršenje. Beograd: Privredna štampa

Perić, O., Milošević, N., Stevanović, I. (2008). Politika izricanja krivičnih sankcija prema maloletnicima u Srbiji. Beograd: Centar za mir i razvoj demokratije

Radulović, Lj. (2010). Maloletničko krivično pravo. Beograd: Pravni fakultet

Radulović, Lj. (2010). Funkcija obrazovanja u suzbijanju maloletničkog kriminaliteta. Strani pravni život. 1. 145-168

Selinšek, Lj. (2007). Kazensko pravo, Splošni del in osnove posebnega dela. Ljubljana: GV Založba

Simonović, B. (1991). Kriminološki, krivičnopravni, krivičnoprocesni i kriminalistički aspekti motiva krivičnog dela, doktorska disertacija (neobjavljena). Kragujevac: Pravni fakultet

Singer, M. (1992). Krivično pravo i kriminologija. Zagreb: Globus

Stojanović, Z. (2012). Krivično pravo, Opšti deo. Beograd: Pravna knjiga

Republički zavod za statistiku. (2014). Maloletni učinioci krivičnih dela - prijave, optuženja i osude. Bilten br. 588

Rešenje Vrhovnog suda Srbije, Kž. 27/2002 od 26. februara 2002. godine. Revija za kriminologiju i krivično pravo. 1 (2005). 84 
Ćirić, Z. (2013). Sudska psihijatrija. Niš: Centar za publikacije Pravnog fakulteta Ćorović, E. (2013). Neke pravnoteorijske dileme u kažnjavanju maloletnika. Revija za kriminologiju i krivično pravo. 1 (51). 49-62

Hrnjica, S. (2003). Opšta psihologija sa psihologijom ličnosti. Beograd: Naučna knjiga

Škulić, M. (2011). Maloletničko krivično pravo. Beograd: Pravni fakultet

Др Душища Миладиновић-Стефбановић,

Доцент Правног факултета, Универзитет у Нишу

\title{
МАЛОЛЕТНИЧКИ ЗАТВОР - НАПОМЕНЕ О СПЕЦИФИЧНОСТИМА РЕДОВНОГ ОДМЕРАВАЊА
}

\begin{abstract}
Резиме
Систем малолетничког кривичног права у Републищи Србији садржи различите механизме реаговања на малолетничку делинквенцију, почевши од васпитних налога, преко васпитних мера, до малолетничког затвора. Овај рад је посвећен проблему редовног одмеравања једине казне предвиђене за малолетнике. Законодавац је за одвијање овог процеса поставио неколико смерница: распон казне малолетничког затвора, сврху кажњавања, степен зрелости малолетника, време потребно за његово васпитање и стручно оспособљавање, али и све релевантне околности из чл. 54. Кривичног законика. Поменута констатација открива и централне теме и систематику даљег излагања, пред којим се налазе два задатка - прво, да се објасни дејство посебних околности из Закона о малолетним учиниоцима кривичних дела и кривичноправној заштити малолетних лица, и друго, да се установи како се опште околности из Кривичног законика примењују у овом случају, са посебним освртом на њихове специфичне манифестације.
\end{abstract}

Кључне речи: малолетнички затвор, сврха кажњавања, олакшавајуће и отежавајуће околности. 